\title{
The Main Principles of the Terminology Work of Old Georgian Translators in the 10th-11th Centuries
}

\section{LIA KAROSANIDZE}

\author{
Arn. Chikobava Institute of Linguistics \\ at Ivane Javakhishvili Tbilisi State University, Georgia
}

\begin{abstract}
The Georgian terminology work has its own long history but it has not been yet studied thoroughly. The basic principles of the Old terminology work followed by the medieval scholars, namely: deep and thorough knowledge of the main notion denoted by a term to render it properly; avoid the norms which are not natural for the Georgian language; try to learn thoroughly the structures of both languages and make them closer, to determine the rules which those languages follow, find right correspondences and not to make mechanical calques; create the Georgian terms with Georgian roots and Georgian derivative means; give precise and trustful definitions. The theories of the old Georgian translators are actual and important up today.
\end{abstract}

KEYWORDS: terminology, old Georgian translators, old Georgian terminology, grammatical terminology, Dionysius Thrax.

\section{ANOTACIJA}

Gruzinų terminologijos istorija yra sena, tik ji nèra išsamiai tyrinėjama. Pagrindiniai viduramžių mokslininkų taikyti senosios terminologijos principai: išsamiai nagrinèti terminu žymimos sąvokos esmę, kad būtų galima sąvoką tinkamai perteikti, vengti gruzinų kalbai neiprastų normų, stengtis kuo labiau perprasti abiejų kalbų struktūras ir jas artinti, nustatyti toms kalboms būdingas taisykles, ieškoti tinkamų atitikmenų ir nekurti vertinių, kurti gruziniškus terminus su gruziniškomis šaknimis ir vedybos priemonemis, teikti tikslias ir patikimas apibrèžtis. Tokios senosios gruzinų kalbos vertejjų taikytos teorinès nuostatos aktualios bei svarbios ir šiandien.

ESMINIAI ŽODŽıAI: terminologija, senosios gruzinų kalbos vertejjai, senoji gruzinų terminologija, gramatikos terminija, Dionisijas Trakietis. 


\section{N T RODUCTION}

The whole history of the Georgian language with its scientific and grammatical competence level proves that there have always been permanent and purposeful terminological researches provided. Alongside with the historical event when Christianity was introduced as the official religion in Georgia, scientific work on Georgian terminology became necessary simultaneously with the demand of translating the Christian literature skillfully, in proper scientific language. Development of general literacy and competence naturally conditioned the necessity of well-developed lexicography without which the translation work would have been impossible to be done. In its turn, as the translation work was developing gradually, it became necessary to solve the problems of developing the perpetual terminological researches and compiling the necessary dictionaries. The Georgian clergymen, working on translations in the monasteries got their education mainly in Greece. Their high-level knowledge in theology and translating skills provided the high-level translations and terminology work as a whole.

Studying the terminology work methods shows clearly that the methodology chosen by the Georgian authors and translators do not differ from the terminology work defined by the modern standards.

\section{OLD GEORGIAN EDUCATIONAL}

AND SCIENTIFIC CENTERS

The level of the scientific work done in a country in such fields as terminology, translation and lexicography depend on political stability in the given country and on the country's aspiration to cultural development. Through all its history of its existence education always have been the main orienting point. Georgian kings never ever had rich palaces but the fact is that there are not so many countries having so many educational centers within a country or out of its borders, as Georgia used to have in those times. As soon as Christianity was introduced, in the 5th-6th centuries, there emerged elementary schools in Georgia where first of all the Holy Bible was taught and the clergymen were trained. The schools became especially popular since the time when the Georgians became familiar with the Byzantine School. It is well known that Georgia had close ties with Byzantium since the 10th century when a strong cultural-edu- 
cational movement began. That was exactly the time when the great cultural and educational renaissance began. Many Georgians, especially from noble families, went to Byzantium temporarily to get good education or sometimes stayed there for all their lives. Later, in the 11th century, Constantine Monomachos founded the Academy which became a place of study for some of the world's best scientific thinkers in this epoch. The cultural-educational movement broke through the borders of Constantinople and Byzantium as a whole and involved those who were called at those times "Christian barbarians", absorbing their vivid creative forces. Many creative people from the East or West were making their way to Constantinople. There they absorbed their culture and made their own contribution to its growth and development. Georgia could not be and really was not an exception from this process; in the 9th-10th centuries Georgia often intersected with Greek culture on the peripheries, and in the 10th-11th centuries, it suddenly rushed right to the center of Byzantine culture through Iviron, Petritsoni and other monasteries. Georgia could now directly see the processes which interested all the Christian nations (Kekelidze 1960: 61-66).

The scholars who became leaders of the cultural-educational processes in that period, all had got an education in that Academy.

The 10th-11th Centuries have marked a very important historical achievement with the foundation and establishment of the educational and scientific centers at the Gelati and Ikalto Academies. Both centers were strong hubs higher learning focusing on subjects including science as philosophy, history, rhetoric, and grammar were taught and researched alongside geometry, arithmetic, astronomy, music, and medicine. Such trade crafts as forging, ceramics, wine farming and vinting (Tevzishvili 1938: 45).

Academician S. Kaukhchishvili argued that Art of Grammar by Dionysius Thrax was known among the grammatical schools functioning in Georgia. Kaukhchishvili founded his opinion on the fact that the Shatberdi Codex was written in the 10th century and this book included some theses written by Diomedes, a grammar scholar of the Art of Gramma by Dionysius Thrax, and the chapter concerning the Greek alphabet was written in accordance with them (Kaukhchishvili 1923: 178-184).

There are many texts of different types compiled together in the Shatberdi Collection: theological, historical, grammatical and others. The pur- 
pose of this manifold manual is only one: its compiler wanted to gather such scientific works which in his opinion had certain comprehensive educational significance. The Shatberdi Collection contains the tutorial texts in such branches as chronology, grammar, natural science, theology, and others. This collection is the most characteristic among other manuscripts of such type. It shows the level of knowledge and interests of the epoch and of the social layer where it was created and for which it was designed (Shatberdi 1979: 9).

A special position named as "teacher of teachers" [modzghvart-modzghvari] existing in the 11th c. in Georgia also reflects the special attitude to education as something important in Georgia. According to the Georgian State Court jurisdiction in that time, this position was more honorable than the religious position of Catholicos. The person in this position lived in Gelati and governed all the issues and processes related to education. In the modern sense of the term, this person was in position of the modern times' minister of education. Such respect shows how much attention was paid to educational processes in Georgia in those times.

\section{THE OLD GEORGIAN TERMINOLOGY SCHOOL}

In the 10th-12th centuries when Georgia was politically united and strong the national self-awareness rose up. National awareness usually is revealed in the process of translating and in its characteristic features. When translating the ecclesiastic books, the Georgian translators used to supply the books with their comments; they did not translate literally word by word but their translation was creative. They related the translated material to their church and its traditions or added some material which they had got as a heritage from the previous centuries' traditions. Sometimes the texts were abridged, or just the opposite - widened with the material which they had got as a heritage from the earlier experiences and traditions, so texts underwent a sort of editorial work. This is the reason that some writings translated from Greek, being clerical or other, were recognized as Georgian writings, and not translated ones. It also should be noted that the Georgian-Byzantine relationships were not unilateral. Georgian literature in its turn somehow influenced and enriched the Byzantine literature: 1. There are some writings, some Byzantine texts preserved only in Georgian as the original Greek texts are lost; so they 
could be read-only as translated into Georgian; 2 . There is such information about some Old Byzantine writers kept in the Old Georgian writings which add new information or show new point of view concerning their life and their creative work; 3. Old Georgian translated literature keeps the information even about the writers who are not well known in the history of the Byzantine literature; 4. The works translated by Old Georgian translators enriched Byzantine literature with the writings translated from Old Georgian; 5. Georgian writers even wrote some works originally in Greek (Kekelidze 1960: 55-56).

The development of literacy itself determined the necessity of lexicographic work. It was necessary to lead translational activities. In its turn, translational activities strongly required explanatory, bilingual and encyclopedic dictionaries to be compiled; it was a desperate need. Each translator and even scribes should have known Georgian language lexis and the rules of word derivation fundamentally, to the same extent as it was necessary for the authors of the original texts. Thus we shall look for the roots of the Georgian lexicography in the writings of the old times Georgian translators. Undoubtedly, the first Georgian lexicographer, in the just specific meaning of the word, must have been the first author-translator. The scholium and marginal comments added to the old translation works provide us with the precious lexicographic notes.

Historically, the cultural and educational development of Georgia was tied to the great successes of the country's historical persons working in the scientific and cultural fields. One such group are the founders of the Athonite Monastery of Iviron: Ioane Mtatsmindeli (920-1005) and Eqvtime Mtatsmindeli (955-1028) along with Giorgi Mtatsmindeli (10091065) which were instrumental in setting up established scientific standards and practices for that time. Also, it is important to note the work of Ephrem Mtsire, a Georgian philologist and philosopher of the second part of the 11th century, who developed theories of translation; Ioane Petritsi (11th-12th centuries), who founded the Petritsoni School; and Arsen Ikaltoeli, the first rector of the Ikalto Academy.

Observing the oldest documents and creative works of the mentioned scientists, we will become sure that they were well educated in lexicography. The works by Ephrem Mtsire and Ioane Petritsi show us the highest level of education and scientific skills of their authors. Their original 
works and translations represent the models of proper work on the Georgian lexis, its study, and development. These works are a kind of lexicographic handbook, full of new terminology.

The existing level of terminology work is a direct indicator of the development level of any given branch of science. Developed terminology is a precondition for a branch of science to develop and reach perfection. Terminology needs systematic work on its enrichment and improvement which allows having scientifically rich and valid original or translated scientific works.

The scientific-philosophical terminology was going on its way of development during centuries. The terms denoting the notions belonging to different branches of philosophy, theology or natural sciences are often used in the writings of several genres but those terms were created in different times by different authors and it was necessary to establish consistent terminology systems for different branches. The rules developed and used by Greek scholars presented a model for the Georgian translators though they did not ever blindly follow them. The first name which we met when looking through the long way of Georgian terminology creation and development is Giorgi Mtatsmindeli, one of the Georgian religious persons and translators. When comparing his translation works with all others it becomes clear how large and serious his contribution is in the development of Georgian philosophical and natural sciences terminology. Unlike the instants where the notions are rendered by phraseology, Giorgi Mtatsmindeli provides one-word terms. He often uses the Greek language term construction but he uses Georgian rules of word formation and renders the notion content of the Greek term in Georgian.

Ephrem Mtsire gave special importance to the exact translation of a term. This can be seen from the fact that he considered it necessary to show the explanation of the words on the margins of the manuscripts in order to facilitate finding of the needed term-word for the reader. The Old Georgian scholars approached the problem with great responsibility taking into consideration etymology of the Greek lexemes studied their meaning thoroughly and gave the exact basic or contextual correspondences in Georgian.

The special role in creation Georgian philosophical terminology belongs to Ioane Petritsi the scholar who determined his methods of the terminological work: he created scientific terminology based on the popular language 
material although considering that those terms should have been different from colloquial lexis by their forms and derivative means. Ioane Petritsi absolutely excluded mixed types - integration of the Greek derivatives and Georgian roots. This requested scientific bravery - quite rich and multifunctional tools of derivation in Georgian should have been given large opportunities; their abilities would become clear and well known for the users; the mighty of the Georgian language not only as the language of poetry but as multifunctional language good for scientific work would be shown; besides, many archaic forms would reinforce and at the same time vivid and perspective word forms would also find their way in terminology.

The most important fact is that Georgian translators of those times had excellent knowledge of Georgian grammatical structure, lexis and the system of word-formation; they tried to enrich the Georgian language with new words and expressions. The Old Georgian translators demonstrated broad knowledge in lexicography, its traditions and in large material accumulated in the works of the Greek and Byzantine lexicography. The well-known Georgian lexicographer of the 20th century, Alexandre Glonti named the scientific works by Georgian lexicographer Ephrem Mtsire alongside with such great Georgian scholars as Ioane Petritsi, Ekvtime Mtatsmindeli and Giorgi Mtatsmindeli and others, as the source of the Georgian lexicography. The first known Georgian Explanatory Dictionary is compiled by Ephrem Mtsire. It is enclosed into the Georgian translation of psalms as an introduction. "The middle part of the introduction to the psalms collection translated into Georgian can be considered the first dictionary compiled in Georgia" (Glonti 1955: 35-37).

From the terminology work viewpoint, the role of Gelati monastery school is special among others in the history of the Georgian literaturescientific language development. The Antic and Christian cultural traditions happened to merge together in Gelati. The well-arranged system of the Georgian philosophic-theological terminology was developed there. Gelati Academy was a typical educational center of the medieval centuries where the Byzantine intellectual thinking of the Renaissance epoch continued its development based on the Georgian traditions. This school stood on the mainline which a little later was followed by the whole European world (Melikishvili 1999).

Gelati school writers gave way to the changes taking place in the vivid speech to flow into their translation theory and practice making the lan- 
guage more easy and understandable for common people. Gradually, the language style of Gelati, so-called Gelaturi, have been clearly developed, its theoretical linguistic base created by Ioane Petritsi. In this style of writings, we see and feel creative boldness and wide scope of knowledge, creative language skills, esthetical thinking, knowledge in philosophy and theology - all in harmony. We should feel gratitude to Ioane Petritsi and his school for philosophy terminology existing in Georgian, based mainly on the word stems and roots of the Georgian origin while in European languages those terms mainly have Greek or Latin roots. From the philosophical viewpoint the Hellenic language was rich and Ioane Petritsi tried to equalize Georgian language lexical-grammatical possibilities to it while not mechanically translating the terms but creating and founding Georgian terminology to deliver the essence of the philosophical terms (Glonti 1983: 75).

Terminological accuracy always was especially important when translating theological works. Surely, the Georgian translators knew about the accusations brought to Ioane Italos by the court. One of those accusations concerned his inaccuracy towards the terminology determined by the Church. He was accused of using not exactly the word-phrases which were determined by the clericals to be used in the field of orthodox religious writings (Melikishvili 1999: 23).

There were two main problems standing in front of the Georgian translators: from one side it was clear that deviation from the Greek language rules, from the terminology which they had determined, could have been regarded as heresy and from the other side making the just word-by-word translation would have protected the translator from accusation but could damage the Georgian language peculiar character imposing the forms unnatural for its grammar. One of the problems which the Georgian translators faced was about the articles. There is no article in Georgian. Using the word "God" without article caused a negative attitude among the Greek clericals and specialists and they accused Georgian translators of heresy. So, it was the difficult road that the Georgian ancient translators overcame successfully. The Georgian translators of the Christian literature followed the religious dogmas and at the same time, they principally stood against the grammatical influences of the other language (Karosanidze 2017: 104). 
3. THE GEORGIAN GRAMMATICAL TERMS

IN THE 11 TH CENTURY

The education obtained in Greece naturally included grammatical knowledge as well. And it is precisely the thorough study of Greek grammatical thought and examination of Georgian grammar through this perspective which underlies and is characteristic for the works of Georgian scientists in the 10th-11th centuries.

It is clear that the 10 th -12 th centuries are currently considered to mark the beginning of the history of Georgian grammatical thinking only since the work dated earlier has yet to be found. The Georgian literary heritage, translated and original works, clearly indicate the existence of great experience and knowledge, and Georgian grammatical thought as a branch of science is naturally supposed to be part of this heritage. Today we can surely say that the Art of Grammar by Dionysius Thrax which is supposed to be the foundation of all-European grammatical thought, must have been well known as an original or through some commentaries, in the Old Georgian literature. Though we do not have the full translation of the text, it can be confirmed by several facts that Greek grammatical theories were not unfamiliar to Georgian scholars, and their philological practice involved the necessary knowledge which was meant by the Byzantine educational system of those times (Karosanidze 1998: 15).

Despite the fact that some information of grammatical character still need to be found and evidenced in Georgian literature, the material which is already obtained allows to imagine the level of grammar knowledge among the Georgian translators of the Old times.

Georgian linguist Mzekala Shanidze relates the oldest original Georgian grammar treatise (with the manuscripts dated back to 12th-13th and 14th centuries th-6, sh-312), named About Articles to the literary school of Ephrem Mtsire. It is one of the most important written monuments according to which the beginning of the Georgian grammatical thinking goes back to the 6 th-7th centuries and decisively proved that the linguistic researches of the 17 th-18th centuries on the linguistic traditions existing in Georgia in the 10th-11th centuries which in their turn relate to the Greek linguistic traditions.

Though the reason for this treatise to be written as a practical type issue which emerged when translating a religious text, About Articles itself represents a separate scientific work. It is an original religious treatise 
written by the Georgian writer, in which one of the grammar issues is discussed and the questions of both- Greek and Georgian grammar are observed and compared (Shanidze 1990: 13-14).

The author explains the essence and designation of an article in the Greek language to a Georgian reader, adding some useful remarks towards the nature and peculiarities of the Georgian language; he also gives some examples so as to make the grammar issues more clear:

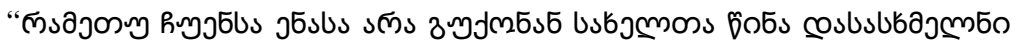

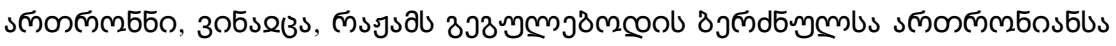

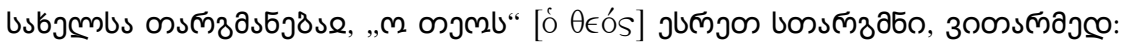

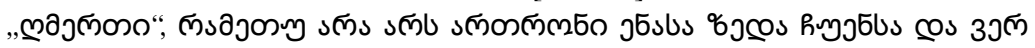

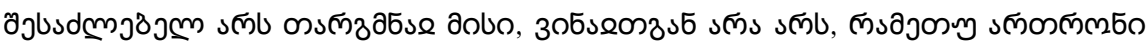

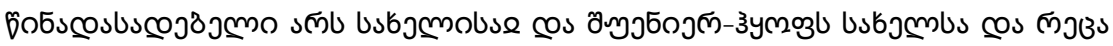

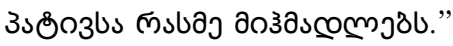
"as our language does not have the article as to put before the nouns when someone wants to translate Greek noun which has an article (o $\theta \in o ́ s$ ) this should be translated us "theos" - "God". The article is that precedes the noun and is important and underlines respect to the special character of that noun, but we do not have this feature in our language" (Shanidze 1990: 134, 6).

There are the terms denoting gender, case, number or other gram-

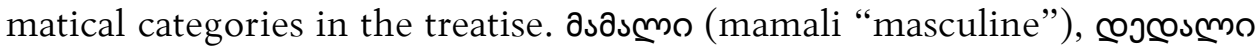
(dedali "feminine"), and ays (shua "medium”). These Georgian terms correspond to the Greek terms.

Five cases are distinguished for the Greek articles:

- sсозомпљооо (advilobiti "nominative")

- Әмдоммдооо (shobilobiti "genitive")

- аозјдооо (mitsemiti "dative")

- до\%ృ\%мдооо (mizezobiti "causative")

- 6møృjooso (tsodebiti "vocative ")

The order and the names of the noun cases are just the same as in Grammar by Dionysius Thrax.

a) sсозоммзљооло (advilobiti "simple") - In the Art of Grammar of

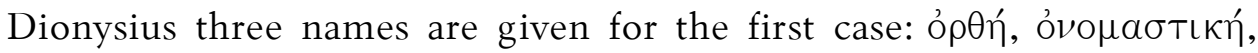
$\epsilon \dot{U} \theta \in \tilde{\imath} \alpha$ (Uhlig 1883).

In the Old Georgian written sources, the following terms exist for the

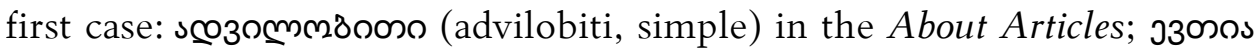
(evtia) and мпооо (orti) (in Georgian translations of works by Amonius

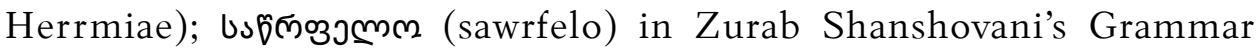




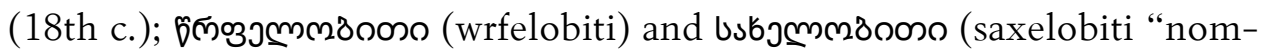
native") in the grammar of Anton I (18th c.) (Karosanidze 1998: 23).

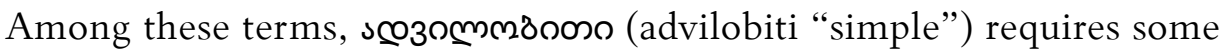
explanation.

In the specialist literature, the Greek term $\epsilon \dot{U} \theta \in \tilde{i} \alpha$ is commonly translated as "direct case" and ópӨń means the same thing - "direct" or "frank". Therefore, out of the three names belonging to the first case ỏ $\rho \theta \eta$, $\in \dot{U} \theta \in \tilde{\imath} a$,

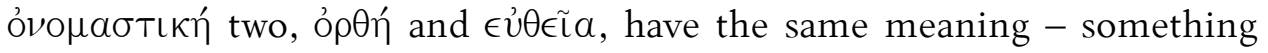
I find somewhat surprising.

The basic meanings of $\epsilon \dot{U} \theta \in \tilde{\imath} \alpha$ in the Greek sources are "direct", "simple", and "relevant", In the Georgian translations of Ammonius Hermiae, the leader of the Alexandrian school (5th-6th centuries), this case has the meaning of "proper". At the same time, however, the translator does not translate the term jзosos $(\in \dot{U} \theta \in \tilde{\imath} \alpha)$ and only transliterates it as the name of the first case. The main meanings of this word are also confirmed in the materials of the Greek-Georgian historical dictionary; Moreover, there is one place in the Gospel of Luke where the Greek $\epsilon \dot{v} \theta \in \tilde{\imath} \alpha$ is trans-

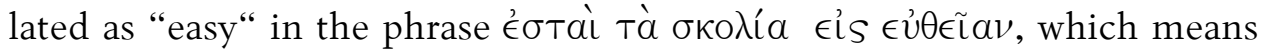
"turn difficult into easy" (Karosanidze 2017: 65).

In commentaries on the section of Art of Grammar by Dionysius Thrax concerning the noun cases, the term $\in \dot{v} \theta \in \tilde{\mathrm{L}} \alpha$ comes from the word $\epsilon \dot{v} \theta \dot{v}$ татоS, which is the superlative degree of the adjectives $\in \dot{U} \theta \dot{u} S \| \in \dot{U} \theta \in \tilde{L} \alpha$ and it has various meanings (Scholia 1901: 545-546).

There are some interesting places in the commentaries which allow us to suppose that this Greek word has exactly the meaning presumed in the Georgian (by which we mean the terms "simple" and "easy").

I. It is the suggestion of Heliodor that $\epsilon \dot{U} \theta \in \tilde{L} \alpha$ is the first case because it does not have a grammatical form, but the following cases, being formed out of it, do have a grammatical form (Scholia 1901: 546-547).

II. Stephan goes on to say that in the $\in \dot{U} \theta \in \tilde{\imath} \alpha$ case a noun is unextended (Scholia 1901: 549).

Anton I explanation of the rectus case should be noted here:

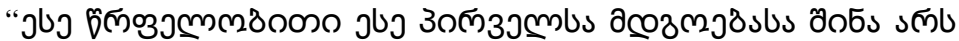

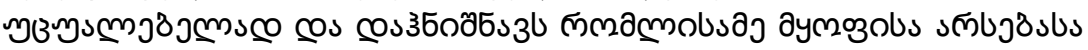

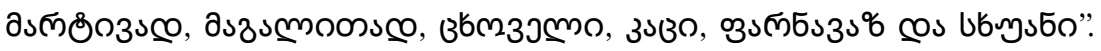

"...rectus always is in the first place and is unextended and denotes any being or thing simply; for example, an animal, a man, Parnavaz, etc. (Anton I 1885: 134). 
Thus when a noun is in the rectus case, it denotes any object in its initial state, exactly, directly and in a simple way. Gaioz Rector (18th c.) explains the first case nearly the same way:

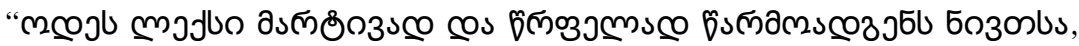

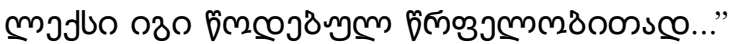

"When a word simply and directly represents an object, it is in the rectus case" (Gaioz Rector 1970: 157).

According the discussion by the commentators of Art of Gramma and explanations made by several Georgian linguists, the noun in the $\epsilon \dot{U} \theta \in \tilde{\imath} \alpha$ case is simple and unextended. ${ }^{1}$

Thus we can conclude that the Greek term $\epsilon \dot{U} \theta \in \tilde{\imath} \alpha$ is based on such characteristics as "simple, easy" and the Old Georgian grammar term

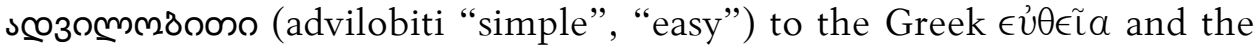
Georgian version conveys the precise meaning of the original Greek term.

It was precisely based on the Old Georgian grammatical treatise based that we are able to translate the first three case terms in the Georgian

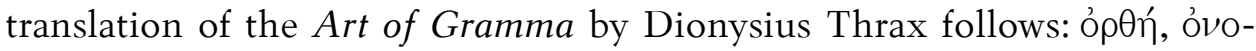

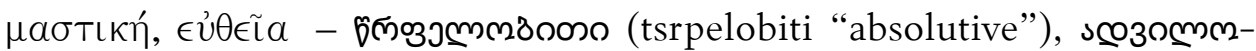

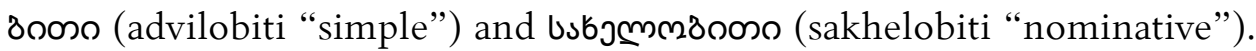
This is despite the fact that in the Russian, German and English translations these two terms are translated with only one term, likely following the Latin tradition ${ }^{1}$.

b) бмљоммљооо (Shobilobiti "Genitive")

In the Old Georgian grammar treatise, two terms are used for the second case (genitive): Бsonjusmzooso (natesaobiti "relatives") and the syn-

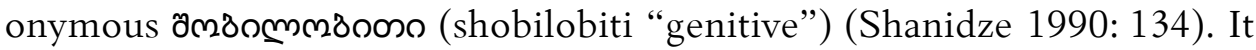
is clear that both terms come from the Greek term. We think that the origin of the Georgian term zmzommznoso (shobilobiti "genitive") reflects the judgment of the commentators of the treatise by Dionysius Thrax about etymology of Greek $\gamma \in \nu \iota \kappa \eta$ : it is called $\gamma \in \nu \iota \kappa \eta$ (genetive) based on the fact that it is genitive, it generates, it is a mother case for the indirect

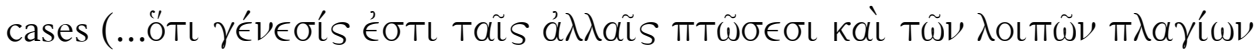

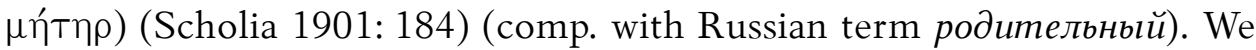

1 The Georgian translation of Art of Grammar by Dionysius Thrax was first published in our book Art of Grammar by Dionysius Thrax and the Old Georgian Grammatical Thought (1998, 2000); and its edited version was published in the book Antique and Byzantine Theories about the Language and Georgian Grammatical Thought (2017). 
find this explanation in the comments by Heliodor and this confirms once again that the Georgian scholars were deeply familiar with the grammar theories popular in Byzantium.

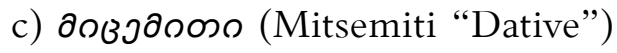

In almost all languages the third case is named with the term which corresponds to Latin Dative, as related to the verb "give" (lat. dativus

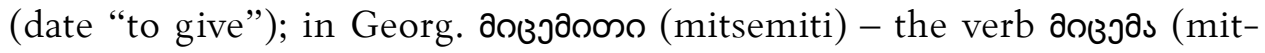
sema "give"; rus. дательный (давать "give”).

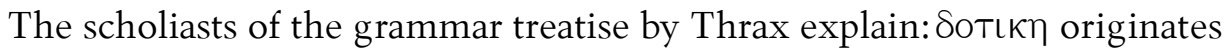

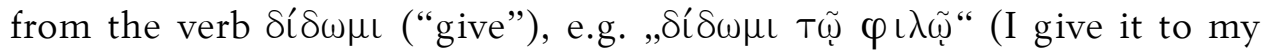
friend) - in this sentence $\tau \tilde{\omega} \varphi(\lambda \tilde{\omega}$ is in the dative case (Scholia 1901: 184).

The author of the Georgian grammar treatise, naturally, explains the terms дозjдоoso (mitsemiti) as exact translation of the Greek term to Georgian:

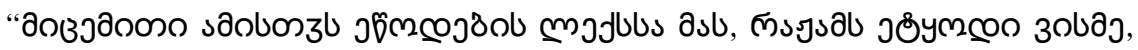

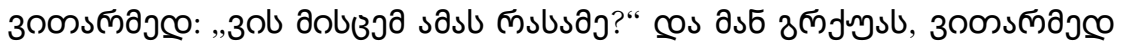
"लةjलूols".

Dative is given as a name to this case because you can imagine the phrase as if you are asked "to whom you will give this?" and the answer will be "to God" (Shanidze 1990: 135-136, 10).

d) до\%っ\%мљоюо (mizezobiti “Causative")

There exist different opinions about the origin of this case name. The term aiтıатьки́ is discussed as related on one side to the verb aiтıáoua "to accuse" (this is reflected in the Latin name of the case - accusare - accusativus, and the same about the Russian Винительньий падеж); and on the other side it is the word aiтıатóv"a cause" (it is evidenced in the treatise About Articles, and as can be seen below, in the Georgian translation of the treatise by Ammonious (Hermeiae) About ten Categories as well).

The most common opinion among the scholiast is that the term under discussion should be understood as related to the word aitıatóv "cause" and translated accordingly. In his work Essays on Classical Philology, Alfred Gudeman reviews the history of Latin and Greek terms and he discusses in detail the translation of Greek terms into Latin. In his view, the Latin translation of aiтıатóv as Accusativus is incorrect and it should have been translated as Causativus (Gudeman 1909: 230-232). Gustav Uhlig, the editor of Art of Grammar by Dionysius Thrax has the same opinion (Uhlig 1883: 32).

Thus, according to the opinions expressed by Alfred Gudeman and Gustav Uhlig, we can conclude that the Georgian term до\%ј\%мдsoso 
(mizezobiti "causative") corresponds more precisely to the original Greek term. Had those scholars known the Georgian term at that time they could have mentioned it as the oldest translation of the Greek term to support their own views. Basing on the writings of the Old times transla-

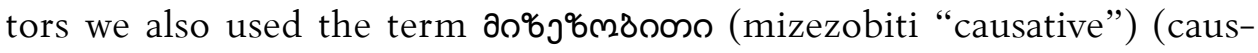
ative) to match the Greek aiтıатıкń.

We should also point out that the author of the treatise had discovered the formal distinction between the Greek aiтıатıк' and the dative and proved there that there is no such difference between the corresponding Georgian forms:

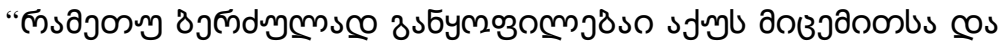

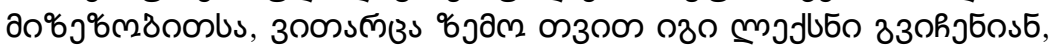

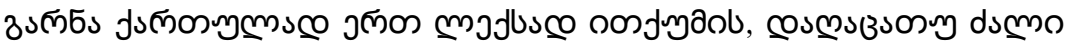
мलू sfull".

"In Greek there are two different forms for the Dative and Accusative, but, as shown above, in Georgian there is one form that has two syntatic functions"... (Shanidze 1901: 73).

e) The fifth case is called faşoðooso (wodebiti "vocative"), which corresponds exactly (in exact correspondence - check this structure/pat-

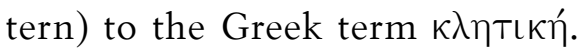

In conclusion, this small grammar treatise is important for our understanding of the history and development of Georgian grammatical thought because was the first to compare the Greek and Georgian grammatical systems and make the following observations:

1. There is no article in Georgian;

2. There is no dual number in Georgian;

3. The Greek noun case forms of dative and causative have only one corresponding form in Georgian.

However, the best proof of the Georgian Grammar of eleventh century great scientific value is that this work has preserved the Old Georgian grammatical terminology down through the centuries and the same terminology is still used today (Karosanidze 2017: 104-109).

Studying thoroughly the Old Georgian terminology we can see that scientific-translational and terminological working process led by the Old Georgian translators was based on such proper methodology which can be in some respect successfully used even nowadays. The special program of the modern Georgian term banks gives us the opportunities to study 
the problems more thoroughly (Georgian Term Bank 2018); to determine the models of the terminology work, to observe Greek-Georgian correspondences, the methodology used by the Old Georgian translators, so that the methodology used by the Old Georgian terminological school becomes more familiar for the modern linguists.

\section{CONCLUSION}

When studying the terminological history of the Old Georgian religious, philosophical, grammar and other branches, the basic principles of the Old terminology work followed by the medieval scholars, namely: deep and thorough knowledge of the main notion denoted by a term to render it properly; avoid the norms which are not natural for the Georgian language; try to learn thoroughly the structures of both languages and make them closer, to determine the rules which those languages follow, find right correspondences and not to make mechanical calques; Create the Georgian terms with Georgian roots and Georgian derivative means; Give precise and trustful definitions.

Finally, it can be said that not only the Old Georgian philosophical, grammatical or religious terminology is extremely important and interesting but the main thing is that the principles and methods of the terminology work used by the Old Georgian translators are useful and considerable nowadays.

\section{REFERENCES}

Anton I. 1885: Georgian Grammar, Tbilisi.

Gaioz Rector 1970: Georgian Grammar. E. Nikolaishvili (ed.).

Georgian Term Bank 2018: Karosanidze L., Ujmajuridze Ir., Jgerenaia E. The Georgian Terminological Database (Electronic Resources for the Corpus of Terminology). Terminological Issues. Ed. L. Karosanidze, TSU Publishing House. Available at: http://termbank.ge/wp-content/uploads/2018/02/term2014.pdf.

The Georgian Language, Encyclopedia 2018: "National Literature" 2008, Tbilisi.

Glonti A. 1955: History of Georgian Lexicography, The Studies I, Tbilisi: Sabchota Sakartvelo.

Glonti A. 1983: Issues of the Georgian Lexicography, Tbilisi: Sabchota Sakartvelo.

Gudeman A. 1909: Gründriss zür Geschichte der klassische Philologie, Leipzig and Berlin.

Hilgard A. (ed.) 1901: Scholia in Dionysii Thracis Artem Grammaticam, Graeci, V. I. Pars. III, Lipsiae.

Karosanidze L. 1998 (2000): “Art of Grammar” by Dionysius Thrax and the Old Georgian Grammar Thought, Tbilisi: Logos.

Karosanidze L. 2017: Antique-Byzantine Theories about Language and Georgian Grammar Thought, Tbilisi: TSU Publishing House.

Karosanidze L. 1995: On the History Some Grammatical Terms Georgian Academy of Sciences, Tbilisi: Metsniereba.

Karosanidze L. 2006: Studies in the History of the Old Georgian Terminology, Tbilisi: Logos.

Karosanidze L. 2014: The Morrow of the Georgian Language. Terminological Issues, Tbilisi: TSU Publishing House. 
Karosanidze L., Khurtsilava A. 2015: For International loanwords in Technical Terminology Dictionary, Arn. Chikobava Readings XXVI, Materials, Tbilisi: TSU Publishing House.

Karosanidze L., Khurtsilava A. 2017: The Problems of Georgian Terminology (History and Modernity), Tbilisi: TSU Publishing House.

Kaukhichishvili S. 1923: Manual of Shatberdi Texts Collection, Moambe III, Tbilisi.

Kekelidze K. 1960: History of the Georgian Literature, vol. 1, Tbilisi: Sabchota Sakartevlo.

Melikishvili D. 1986: Gelati School and the Issues of Development of Georgian Scientific Language, Proceedings of Iv. Javakhishvili Tbilisi State University. - Linguistics 10, Tbilisi.

Melikishvili D. 1988: Literature School of Gelati and the Ways of Development of Georgian Philosophical Language, Tbilisi.

Melikishvili D. 1999: From the History of Old Georgian Philosophical-Theological Terminology, Tbilisi.

Melikishvili D. (ed.) 2009-2010: Old Georgian-Old Greek Philosophical-Theological Documented Dictionary I, II. Compiled by A. Kharanauli, D. Melikishvili, M. Rapava, V. Jugheli, L.Gigineishvili, N. Chikvatia, N. Mrevlishvili, Tbilisi.

Shanidze M. 1968: Introduction to the Translation of Psalms by Ephrem Mtsire (texts and remarks). TSU, Works of the Old Georgian Academic Department 11, 72-122.

Shanidze M. 1990: "About Article" - the Old Georgian Grammar Treatise, Tbilisi.

Shatberdi 1979: Shatberdi Collection of $10^{\text {th }}$ century. B. Gigineishvili, E. Giunashvili (eds.), Tbilisi.

Tevzishvili G. 1938: About the Higher Education in Georgia, Tbilisi: Sabchota Sakartvelo.

Uhlig G. 1883: Dionysii Thracis, Ars Grammatica, Lipsiae.

\section{SENOSIOS GRUZINŲ KALBOS VERTÉJŲ X-XI A. TAIKYTI TERMINOLOGIJOS PRINCIPAI}

Santrauka

Kaip kūrèsi moksliniais metodais grindžiama gruzinų terminologija, matyti iš pirmųjų gruzinų kalbos vertejjų darbų. Tų Gruzijos terminologijos pradininkų darbuose išryškejja du pagrindiniai principai:

1) išsamiai nagrinèti sąvokas, aiškintis jų esmę ir atsiradimo istoriją;

2) turèti daug žinių, atsižvelgti ị kalbos ypatumus ir jos teikiamas galimybes pasidaryti naujų vedinių.

Tik taip galima svetimas, kitoje aplinkoje sukurtas sąvokas patikimai perteikti atitinkamų žodžių darybos galimybių turinčia gimtąja kalba. Gruzinų terminologijos ar kalbos istorijos sričių tyrejjai sutaria, kad X-XII a. naujų terminų daryba buvo produktyvus ir pažengęs procesas ir mes iš tų laikų patirties galime daug ko pasimokyti. Minimasis laikotarpis išsiskiria tuo, kad Bizantijos kultūra, laikoma visų Europos šaliu kultūros, mokslo ir terminologijos pagrindu, ị gruzinų kalbą buvo perkeliama vertéjams nepamirštant pagrindinių savos kalbos ypatybių.

Derinti graikų ir gruzinų kalbų ypatybes - toks buvo mokslinis gruzinų vertėjų ir filologų dirbto darbo principas. Tas požiūris lèmè, kad Bizantijos kultūrą Gruzija skleidè išsaugodama savąią. Senosios gruzinų kalbos vertėjų taikytos teorijos aktualios bei svarbios ir šiandien.

\section{Gauta 2019-08-10}

Lia Karosanidze

Mitskevichi str.18, fl. 10, Tbilisi, Georgia

E-mail1.karosanidze@gmail.com 